\title{
Study on the Toxic Mechanism of Prion Protein Peptide 106-126 in Neuronal and Non Neuronal Cells
}

\author{
Ingrid Dupiereux, ${ }^{1}$ Willy Zorzi, ${ }^{1}$ Walid Rachidi, ${ }^{2}$ Danièle Zorzi, ${ }^{1}$ Olivier Pierard, ${ }^{1}$ \\ Bernard Lhereux, ${ }^{3}$ Ernst Heinen, ${ }^{1}$ and Benaïssa Elmoualij ${ }^{1 \star}$ \\ ${ }^{1}$ Department of Human Histology, CRPP, University of Liège, Institute of Pharmacy-CHU, \\ Sart Tilman, Liège, Belgium \\ ${ }^{2}$ Service de Génomique Fonctionnelle, Bâtiment Génopole 2, CEA, Evry Cedex, France \\ ${ }^{3}$ Laboratoire Roman Païs, Nivelles, Belgium
}

A synthetic peptide corresponding to the 106-126 amyloidogenic region of the cellular human prion protein $\left(\mathrm{PrP}^{\mathrm{C}}\right)$ is useful for in vitro study of prion-induced neuronal cell death. The aim of the present work was to examine the implication of the cellular prion protein in the toxicity mechanism induced by PrP 106-126. The effect of PrP 106-126 was investigated both on human neuroblastoma SH-SY5Y cells and on SH-SY5Y overexpressing murine cellular prions (wtPrP). We show by metabolic assay tests and ATP assays that $\mathrm{PrP}^{\mathrm{C}}$ expression does not modulate the toxicity of the prion peptide. Moreover, we investigated the effect of this peptide on an established non neuronal model, rabbit kidney epithelial A74 cells that express a doxycyclineinducible murine $\mathrm{PrP}^{\mathrm{c}}$ gene. We show for the first time that the prion peptide 106-126 does not exert any toxic effect on this cell line in the presence or absence of doxycycline. Our results show that the PrP 106-126induced cell alteration is independent of $\operatorname{PrP}^{\mathrm{C}}$ expression. Rather, it seems to act via an interaction with lipidic components of the plasma membrane as strengthened by our results showing the differential susceptibility of neuronal and non neuronal cell lines that significantly differ by their membrane fatty acid composition. @ 2006 Wiley-Liss, Inc.

Key words: cellular prion peptide; 106-126 prion peptide; lipid membrane; neurotoxicity

Prion diseases are fatal neurodegenerative disorders affecting the central nervous system (CNS) of humans and animals and characterized by a neuronal vacuolation, astrocytosis, and progressive neuronal degeneration (Gajdusek et al., 1966; Clinton et al., 1993; Fraser, 1993; Jeffrey et al., 2000). These diseases are caused by the intracerebral accumulation of an abnormal isoform of the cellular prion protein $\left(\operatorname{PrP}^{\mathrm{c}}\right)$, named $\operatorname{PrP}^{\mathrm{sc}}$ (PrP scrapie) (Caughey and Lansbury, 2003; Collins et al., 2004; Prusiner, 1998). Many lines of evidence suggest that $\operatorname{PrP}^{c}$ acts as a template that promotes the conversion of $\operatorname{PrP}^{\mathrm{c}}$ to $\operatorname{PrP}^{\mathrm{sc}}$ (Caughey and Raymond, 1991). The plasma membrane seems to play a key role in the molecular mechanism implicated in this conversion. Supporting this hypothesis is the subcellular site for the formation of $\operatorname{Pr} \mathrm{P}^{\mathrm{sc}}$; indeed, the conversion occurs after $\operatorname{PrP}^{\mathrm{c}}$ reaches the plasma membrane (Taraboulos et al., 1995). Moreover, Baron et al. (2002) have shown, using purified raft membranes, that the conversion of raft-associated GPI-anchored $\operatorname{PrP}^{\mathrm{c}}$ to $\operatorname{PrP}^{\mathrm{sc}}$ requires the insertion of $\operatorname{PrP}^{\mathrm{sc}}$ into the lipid membrane. However, the mode of interaction of prion proteins with the membranes has not as yet been elucidated: does the interaction occur via a direct insertion of the prion protein into the lipid bilayer or via a putative membrane receptor?

We have shown previously that $\operatorname{PrP}(106-126)$, a peptide largely used as a model to study the $\operatorname{PrP}^{\mathrm{sc}}$ induced neurotoxicity, destabilizes lipid vesicles mimicking the composition of neuronal membranes (liposomes) and induces liposome fusion (Dupiereux et al., 2005a). This destabilization mechanism occurs at low concentrations of the peptide (from 2-10 $\mu \mathrm{M}$ ) and via a membrane interaction, as supported by the integrity membrane assay measuring the release of the intracellular lactate dehydrogenase (LDH assay). These results are in agreement with other previous reports. Indeed, several studies have shown that PrP 106-126 forms ion channels in planar lipid bilayers (Arispe et al., 1996; Kawahara et al., 2000) and that it increases the membrane microviscosity of

Contract grant sponsor: Région Wallonne; Contract grant number: BA4 114915, EPH331030000092-430001; Contract grant sponsor: Fonds Social Européen; Contract grant number: W2002134; Contract grant sponsor: Commisariat à l'Energie Atomique (CEA); Contract grant sponsor: Laboratoire Roman Païs.

^Correspondence to: Benaïsa Elmoualij, Department of Human Histology, CRPP, University of Liège, Institute of Pharmacy-CHU, 1, avenue de l'Hôpital, Sart Tilman, 4000 Liège Belgium.

E-mail: b.elmoualij@ulg.ac.be

Received 20 December 2005; Revised 21 February 2006, 22 March 2006; Accepted 26 April 2006

Published online 00 Month 2006 in Wiley InterScience (www. interscience.wiley.com). DOI: 10.1002/jnr.20965 
neurons and astrocytes (Diomede et al., 1996; Salmona et al., 1997). Nevertheless, the role of the cellular prion protein in the membrane destabilization mechanism induced by this peptide remains as yet non-elucidated. Several works, using knock-out cell lines, show that $\mathrm{PrP}^{\mathrm{c}}$ expression is necessary for the cellular toxicity induced by this peptide (Brown et al., 1994; Chabry et al., 2003a; Fioriti et al., 2005b). These results indicate that the membrane destabilization induced by PrP 106-126 could arise from a dual mechanism: a direct peptide insertion in the lipid bilayer or an interaction with $\operatorname{PrP}^{\mathrm{c}}$.

To investigate the role of $\operatorname{PrP}^{c}$ in the neurotoxicity induced by the 106-126 prion peptide we have examined whether an overexpression of murine $\operatorname{PrP}^{\mathrm{c}}$ (wtPrP) (Walmsley et al., 2001a) changes the susceptibility of neurons to the peptide. Our results indicate that the toxicity induced by the 106-126 peptide is independent of $\operatorname{PrP}^{\mathrm{c}}$ expression level. Moreover, the addition of an anti-prion antibody (SAF 34), able to decrease the basal level of $\operatorname{PrP}^{c}$, induces, in our experimental conditions, non-significant changes in toxicity, showing that the $\operatorname{PrP}^{\mathrm{c}}$ expression is not necessary for the PrP 106-126 toxicity. Additionally, to study the potential relationship between PrP 106-126 and lipidic components of the plasma membrane, we have investigated the effect of the peptide on non-neuronal cells, rabbit kidney epithelial (A74) cells, which express a doxycycline-inducible murine $\mathrm{PrP}^{\mathrm{c}}$ gene. We have shown that this cell line is resistant to the PrP 106-126 toxicity confirming that the toxicity of this peptide is independent of $\mathrm{PrP}^{\mathrm{c}}$ expression levels. We therefore suggest that this toxicity might be in relation with the lipidic composition of the cell membranes as strengthened by our results after the comparison of the fatty acid composition between neuronal and non-neuronal cells by HPLC fatty acid analysis.

\section{Chemicals}

PrP106-126, derived from amino residues 106-126 of the human prion protein sequence (sequence: Lys-Thr-AsnMet-Lys-His-Met-Ala-Gly-Ala-Ala-Ala-Ala-Gly-Ala-Val-ValAQ3 Gly-Gly-Leu-Gly) was purchased from Eurogentec SA and scrambled peptide containing the same amino acids in a random order (sequence: Asn-Gly-Ala-Lys-Ala-Leu-Met-GlyGly-His-Gly-Ala-Thr-Lys-Val-Met-Val-Gly-Ala-Ala-Ala) was AQ3 purchased from Bachem. Palmitic acid was purchased from AQ3 Sigma Aldrich. The secondary antibody rabbit antimouse IgG, AQ3 A, M/FITC was purchased from Serotec and Streptavidine/ AQ3 FITC from Pharmingen. Rabbit polyclonal antibody P45-66 was supplied by Dr. D. Harris (Washington University, St. Louis, MO) and the secondary antibody HRP-coupled rabbit $\mathrm{IgG}$ was from Sigma (St. Louis, MO). The mouse anti-PrP $\mathrm{P}^{\mathrm{C}}$ SAF34 was kindly provided by Dr. J. Grassi from CEA of Paris. All cell culture supplies were purchased from Life TechAQ3 nologies Inc. and fatty acid supplies were from VWR InternaAQ3 tional and Sigma-Aldrich.

\section{Cell Culture}

The human neuroblastoma cell line SH-SY5Y, kindly provided by Professor N.M. Hooper, and the same line stably transfected with the wild-type murine $\operatorname{PrP}(w t P r P)$ (Walmsley et al., 2001b) were cultured in Dulbecco's modified Eagle's medium (DMEM) (Life Technologies Inc.) supplemented with 10\% fetal bovine serum (FBS) (Life Technologies Inc.), 1\% penicillin/streptomycin (Life Technologies Inc.). Cells were maintained at $37^{\circ} \mathrm{C}$ in a humidified incubator with $95 \%$ air and $5 \% \mathrm{CO}_{2}$. For experiments, cells were maintained in FBS-free DMEM medium containing the neuroblastoma growth supplement N2 (Life Technologies Inc.) and 1\% penicillin/streptomycin.

The A74 cell line, initially generated in the laboratory of Drs. Vilette and Laude (INRA, Jouy-en-Josas, France), was established by transfecting rabbit kidney epithelial cells with murine $\operatorname{PrP}^{c}$. The expression of the murine $\operatorname{PrP}$ is doxycycline-inducible via a tetracycline-inducible (tet-on) system (Vilette et al., 2001d). The stable transfectants were selected in the presence of puromycin $(10 \mu \mathrm{g} / \mathrm{ml})$. A74 were cultured in modified Eagle's medium (MEM) supplemented with 10\% heat-inactivated FBS and 1\% penicillin/streptomycin. Cells were grown at $37^{\circ} \mathrm{C}$ in a humidified incubator with $95 \%$ air and $5 \% \mathrm{CO}_{2}$. For experiments, cells were maintained in MEM medium containing $2 \%$ FBS and $1 \%$ penicillin/streptomycin.

\section{Cell Metabolism Assays}

SH-SY5Y cells were seeded into 96-well culture plates. Sixteen hours after seeding, the medium was replaced with serum-free DMEM containing the neuroblastoma growth supplement N2 and the cells were treated for $24 \mathrm{hr}$ with different concentrations of PrP 106-126 (10-200 $\mu \mathrm{M})$. The treatment with the anti-prion antibody SAF 34 was carried out by incubating the cells with an optimized concentration of antibody SAF $34(1 \mu \mathrm{g} / \mathrm{ml})$ and after $3 \mathrm{hr}$, the medium was replaced with fresh medium and cotreated for an additional $24 \mathrm{hr}$ with PrP 106-126 $(200 \mu \mathrm{M})$ and SAF $34(1 \mu \mathrm{g} / \mathrm{ml})$.

A74 cell line in 96-well culture plates were grown overnight in MEM supplemented with 2\% FBS. The next day the medium was changed and the cells were treated with doxycycline at $500 \mathrm{ng} / \mathrm{ml}$ to induce $\operatorname{PrP}^{c}$ expression. After $24 \mathrm{hr}$ the cells were incubated with $\operatorname{PrP} 106-126(50-100 \mu \mathrm{M})$ for an additional $24 \mathrm{hr}$.

To study the effect of lipidic factors, such as palmitic acid, on the toxicity effect of the 106-126 peptide, both the neuronal (SH-SY5Y) and non neuronal cells (A74) were incubated with palmitic acid at a final concentration of $25 \mu \mathrm{M}$ for $16 \mathrm{hr}$. Cells were then treated with the palmitic acid $(25 \mu \mathrm{M})$ and $\operatorname{PrP} 106-126(200 \mu \mathrm{M})$ for additional $24 \mathrm{hr}$.

The cell proliferation was measured using the CellTiter $96 \mathrm{AQ}_{\text {ueous }}$ Non-Radioactive Cell Proliferation Assay (Promega) according to the manufacturer's instruction. The cell toxicity was assessed quantitatively by MTS assay in the presence of phenazine methosulfate (PMS). After addition of $20 \mu \mathrm{l}$ of the combined MTS/PMS solution in each well, the plates were incubated at $37^{\circ} \mathrm{C}$ in a humidified atmosphere contain- 
ing $5 \% \mathrm{CO}_{2}$ for $2 \mathrm{hr}$. The absorbance was measured at $490 \mathrm{~nm}$ (EL 312e microplate Bio-Tek Instruments).

All MTS assays were carried out in triplicate. MTS assay is a sensitive indicator of mitochondrial activity.

\section{Cell Toxicity Test}

Measurement of ATP levels allows to estimate cellular suffering. Human SH-SY5Y cells were seeded into 96-well culture plates. Sixteen hours after seeding, the medium was replaced with serum-free medium containing the neuroblastoma growth supplement N2 and the cells were treated for $24 \mathrm{hr}$ with different concentrations of $\operatorname{PrP} 106-126(10-200 \mu \mathrm{M})$.

ATP was quantified using the CellTiter-Glo Luminescent Cell Viability Assay (Promega) according to the manufacturer's instruction. The reagent is a buffered solution containing detergents to break the cell membrane, releasing ATP immediately on addition to wells and ATPase inhibitors to stabilize ATP once it is released from cells. After 106-126 peptide treatment, assay plates were removed from the incubator and $100 \mu \mathrm{l}$ of CellTiter-Glo Assay reagent, equilibrated to room temperature, was added to each well. Plates were shaken for $2 \mathrm{~min}$ to $\mathrm{mix}$ the contents of the wells. After a 10-15 min incubation at room temperature, luminescence was determined using a Microplate Luminometer MPL2 (Berthold).

\section{PrPc Labeling for Confocal Microscopy}

A total of 20,000 SH-SY5Y or wtPrP cells were seeded and left to adhere for $5 \mathrm{hr}$ in $50 \mu \mathrm{l}$ DMEM 10\% FBS and 1\% penicillin/streptomycin on uncoated $12-\mathrm{mm}$ circular glass coverslips placed in 24-well culture plates (Greiner). Fresh medium $(450 \mu \mathrm{l})$ was added. Cells were cultured for $24 \mathrm{hr}$ then fixed during $20 \mathrm{~min}$ in $1: 1$ acetone/methanol at $-20^{\circ} \mathrm{C}$. The acetone/methanol was discarded and the coverslips were kept at $-20^{\circ} \mathrm{C}$ until use. The cells were then dehydrated at room temperature and rehydrated in phosphate buffered saline (PBS) before labeling. $\operatorname{PrP}^{\mathrm{C}}$ was revealed at room temperature as follows: cells were incubated $1 \mathrm{hr}$ with SAF34 $10 \mu \mathrm{g} / \mathrm{ml}$ in PBS, washed 3 times with PBS, incubated $30 \mathrm{~min}$ with the rabbit anti-mouse $\operatorname{IgG}, \mathrm{A}, \mathrm{M} / \mathrm{FITC} 1 / 1,000$ in PBS, followed by washing 3 times in PBS. The coverslips were mounted on microscopy glass slides using DAKO fluorescence mounting medium before observation with a Leica TCS SL SP2 confocal microscope (Leica, Belgium) equipped with Argon, Ne/ $\mathrm{Kr}$, and $\mathrm{He} / \mathrm{Ne}$ lasers. One-step scans were carried out. A series of 20 images were acquired and stacked using the Maximum Projection.

\section{Western Blotting}

A74 cells (seeding density $5 \times 10^{6}$ ) were grown in T75 $\mathrm{cm}^{2}$ flasks. The next day the cells were treated for an additional $24 \mathrm{hr}$ with different concentrations of doxycycline $(10-500 \mathrm{ng} / \mathrm{ml})$. After $24 \mathrm{hr}$, the cells were washed twice with cold PBS, calcium- and magnesium-free, and lysed for $30 \mathrm{~min}$ at $4^{\circ} \mathrm{C}$ in Triton-deoxycholate lysis buffer $(1 \times$ buffer is $150 \mathrm{mM} \mathrm{NaCl}, 0.5 \%$ Triton $\mathrm{X}-100,0.5 \%$ sodium deoxycholate, and $50 \mathrm{mM}$ Tris- $\mathrm{HCl}, \mathrm{pH}$ 7.5) containing protease inhibitors. After $1 \mathrm{~min}$ of centrifugation at $10,000 \mathrm{~g}$, the supernatant was collected, and its protein concentration was meas- ured by the BCA assay (Pierce). The equivalent of $20 \mu \mathrm{g}$ of total protein in SDS loading buffer was subjected to $12 \%$ SDS-PAGE electrophoresis followed by electroblotting on polyvinylidene difluoride in Tris-glycine buffer containing $20 \%$ methanol. The membrane was blocked with 5\% non-fat dry milk in TBST (0.1\% Tween 20, $100 \mathrm{mM} \mathrm{NaCl}, 10 \mathrm{mM}$ Tris-HCL, $\mathrm{pH}$ 7.8) for $1 \mathrm{hr}$ at room temperature, and $\operatorname{PrP}$ was detected by immunoblotting with P45-66 antibody. After adding the second antibody (horseradish peroxidase-coupled rabbit $\operatorname{IgG}$ ), immunoreactive proteins were detected with the ECL Western blot system.

\section{Flow Cytometry}

Human SH-SY5Y cells seeded in 6-well plates $(1.6 \times$ $10^{6}$ cells/well) were incubated for $24 \mathrm{hr}$ in the presence or absence of SAF34 at $1 \mu \mathrm{g} / \mathrm{ml}$. The cells were then rinsed in PBS and collected after incubation at $37^{\circ} \mathrm{C}$ for $10 \mathrm{~min}$ with $500 \mu \mathrm{l}$ of cell dissociation buffer (enzyme free; Invitrogen). Samples of $100 \mu \mathrm{l}$ containing $1 \times 10^{6} \mathrm{SH}-\mathrm{SY} 5 \mathrm{Y}$ cells were incubated with the biotinylated antibody SAF34 $(10 \mu \mathrm{g} / \mathrm{ml})$ for $30 \mathrm{~min}$ at $4^{\circ} \mathrm{C}$ in $\mathrm{PBS}$, washed and then incubated for an additional $30 \mathrm{~min}$ with a fluorescein isothiocyanate-conjugated streptavidin (diluted 1/1,000). The control cells were not incubated with the antibody (biotinylated SAF34). After rinsing, the resuspended cells were immediately analyzed in a FACScan (Becton-Dickinson, Sunnyvale, CA).

\section{Fatty Acid Analysis}

Phospholipid extraction was carried out on SH-SY5Y and A74 cells. The cells were placed in $0.1 \mathrm{ml}$ of a mixture of butylated hydroxy toluene (BHT) $/ \mathrm{CH}_{2} \mathrm{Cl}_{2} \quad(0.0204 \mathrm{mg}$ of BHT in $1 \mathrm{ml}$ of $\mathrm{CH}_{2} \mathrm{Cl}_{2}$ ) and $4 \mathrm{~g}$ of $\mathrm{Na}_{2} \mathrm{SO}_{4}$ and crushed with a cooled mortar. After $1 \mathrm{~min}$, Celite $545(3 \mathrm{~g})$ was added and the cells were further crushed for $1 \mathrm{~min}$. The mixture was transferred in a chromatography column filed with glass wool and $2 \mathrm{~g}$ of a mixture of $\mathrm{CaHPO}_{4} \cdot 2 \mathrm{H}_{2} \mathrm{O}$ and Celite 545 in a proportion of 1:9. The mortar was washed with $15 \mathrm{ml}$ of the mixture $\mathrm{CH}_{2} \mathrm{Cl}_{2} / \mathrm{CH}_{3} \mathrm{OH}$ (90:10) and transferred onto the column. About $50 \mathrm{ml}$ of the mixture $\mathrm{CH}_{2} \mathrm{Cl}_{2} / \mathrm{CH}_{3} \mathrm{OH}$ was added and the eluent was collected and diluted in $1 \mathrm{ml}$ of ethyl acetate and the phospholipid fatty acids were separated with a SPE method (solid phase extraction). The trans-esterification procedure of the carboxylic group with methanol in hot acid medium produced the fatty acid methyl esters (FAME). The FAME were separated by gas chromatography (GC), Agilent 6890, on a capillary column with helium as the carrier gas. The analysis was realized with a flame ionization detector. The chem station software, on the GC Agilent 6890, measured the height of the different peaks and calculated the concentrations of the different FAME.

\section{RESULTS}

\section{Toxicity of PrP 106-126 Is Independent of the Level of Cellular PrP Expression}

To study the relationship between the toxicity of PrP 106-126 and the expression levels of the cellular prion protein, we compared the effect of the peptide on SH-SY5Y neuroblastoma cells, expressing a basal level of 


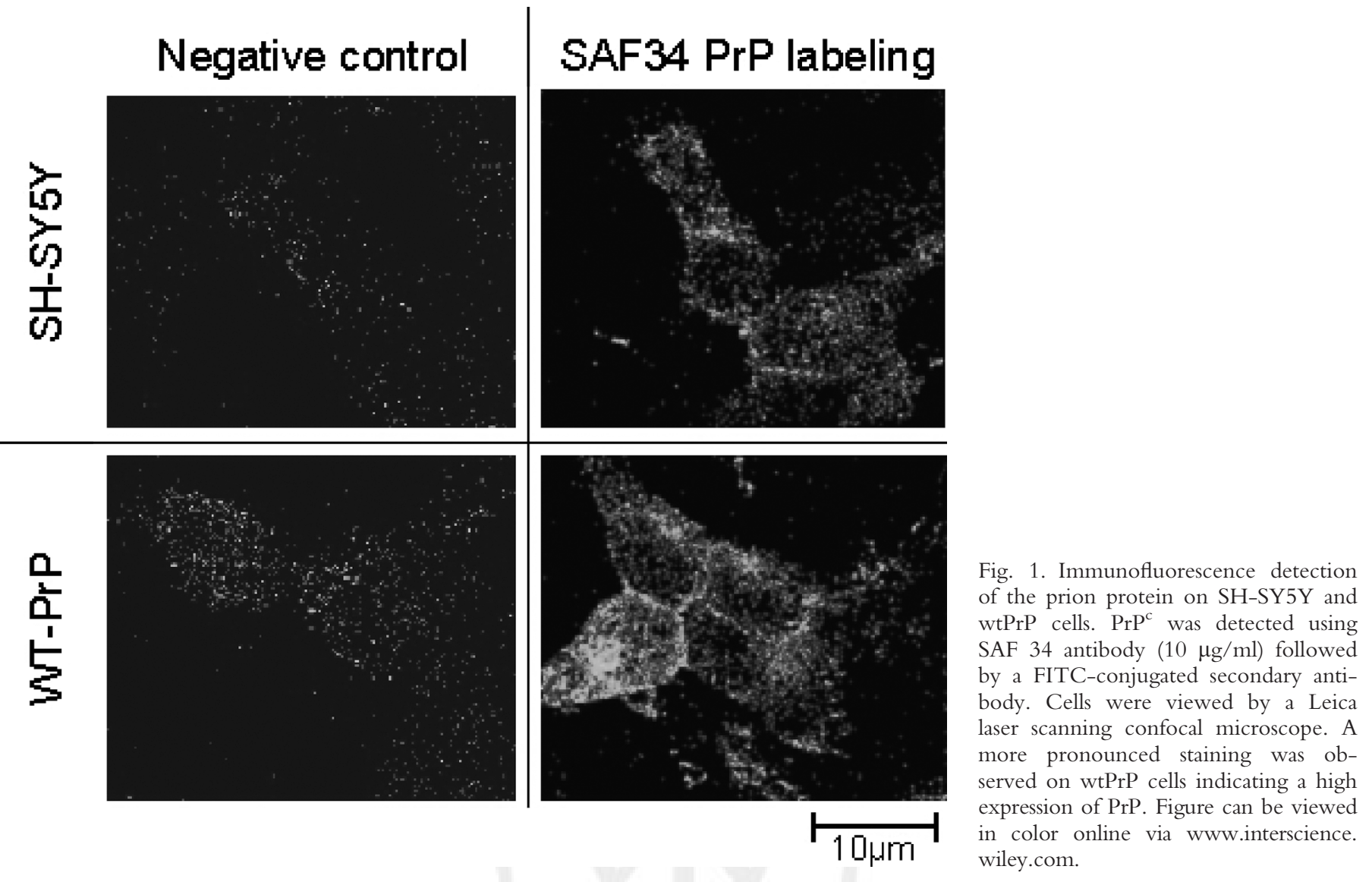

human PrP, with the same SH-SY5Y cells overexpressing a murine prion protein $(\mathrm{wtPrP})$. The level of $\operatorname{PrP}$ expression was analyzed by confocal microscopy using the SAF 34 antibody. As shown in Figure 1, a more intense immunostaining was observed on wtPrP cells, whereas a weak staining was detected on SH-SY5Y cells. These results confirm that the wtPrP cells overexpress $\mathrm{PrP}$ in comparison with the SH-SY5Y cells that express a basal level of PrP.

Neuronal injuries induced by the 106-126 peptide were monitored by measuring the reduction of the mitochondrial activity using the MTS assay and the ATP assay monitoring cell alteration. MTS is converted to a formazan product by dehydrogenase enzymes, which become inactive as the cell suffers. Measurement of this formazan product is an indicator of cell metabolism and viability. As shown in Figure 2A, $\operatorname{PrP} 106-126$ treatment $(10-200 \mu \mathrm{M})$ induces a concentration-dependent toxicity for both SH-SY5Y and wtPrP cells. No significant difference in the toxicity induced by the peptide was observed between the two cell lines; indeed, PrP 106-126 caused a 50\% decrease at $200 \mu \mathrm{M}$ in SH-SY5Y and $\mathrm{wtPrP}(45.9 \pm 3.6 \%$ and $55.8 \pm 11.2 \%$, respectively). In contrast, $200 \mu \mathrm{M}$ of scrambled peptide had no effect $(99.5 \pm 0.96 \%)$ (Fig. 2B). These data indicate that the toxicity induced by the peptide 106-126 is independent of the level of PrP expression.
By using the ATP assay, the effect of $\operatorname{PrP} 106-126$ on the intracellular content of ATP was measured in relation with the level of $\mathrm{PrP}$ expression (Fig. 3). A $24 \mathrm{hr}$ treatment with different concentrations of the peptide $(10-200 \mu \mathrm{M})$ induced a dose-dependent decrease in the ATP level without any difference between the two tested cell lines (SH-SY5Y and WtPrP). These data are in agreement with those obtained with the MTS assay confirming that the toxicity induced by $\operatorname{PrP} 106-126$ is independent of the level of $\operatorname{PrP}^{c}$ expression.

To elucidate whether the neurotoxic effect of PrP 106-126 observed on the neuroblastoma cell lines is mediated by the PrP basal level expression, we blocked $\mathrm{PrP}^{\mathrm{c}}$ surface expression with an anti-PrP antibody. We used SAF34, known to interact with $\operatorname{PrP}^{\mathrm{c}}$ and prevent the interaction between $\operatorname{PrP}^{\mathrm{c}}$ and $\operatorname{PrP}^{\mathrm{sc}}$ (Perrier et al., 2004; Feraudet et al., 2005a).

To investigate the effect of the SAF34 antibody on $\operatorname{PrP}^{c}$ expression, we analyzed by flow cytometry the level of $\mathrm{PrP}^{\mathrm{c}}$ on SH-SY5Y neuroblastoma cells incubated for $24 \mathrm{hr}$ in the presence or absence of the SAF34 antibody. As shown in Figure $4 \mathrm{a}$, in the absence of SAF34 treatment, the neuroblastoma cells SH-SY5Y present a positive immunostaining indicating that they express a basal level of $\mathrm{PrP}^{\mathrm{c}}$ as shown by confocal microscopy (Fig. 1). Conversely, when the cells were pre-incubated with the SAF34 antibody for $24 \mathrm{hr}$ (Fig. 4b) no staining was 
A

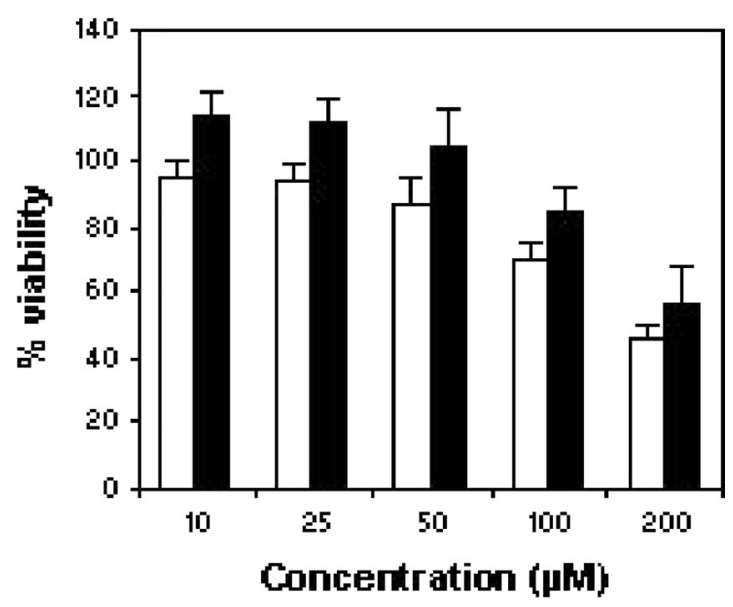

B

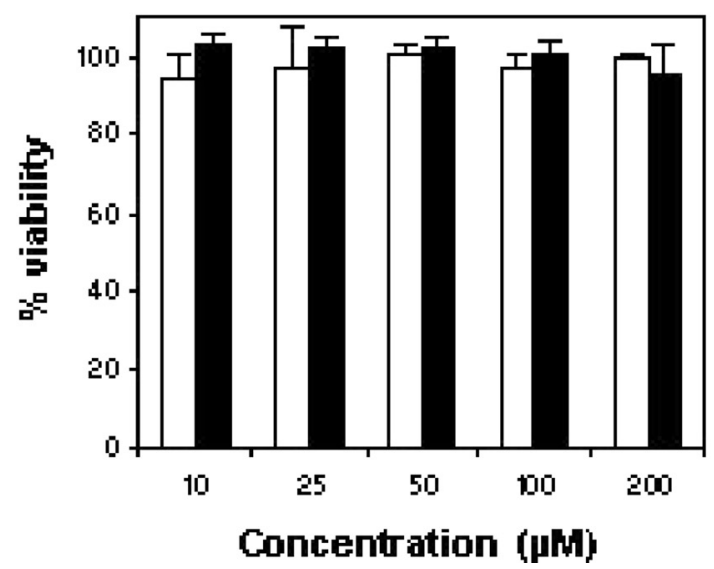

Fig. 2. PrP 106-126 neurotoxicity in SH-SY5Y and wtPrP cells. PrP 106-126 (A) or scrambled (control) PrP 106-126 (B) was added at concentrations of 10-200 $\mu \mathrm{M}$. Cell metabolism (viability) was measured $24 \mathrm{hr}$ later using the MTS assay. PrP 106-126, but not scrambled peptide, altered the metabolic activity of SH-SY5Y (white bars) and wtPrP (black bers) cells in a dose-dependent manner. No significant differences were observed in relation with the level of $\mathrm{PrP}^{\mathrm{c}}$ expression. Each value represents the mean percentage $\pm \mathrm{SD}$ from triplicate experiments repeated three times (nine observations).

observed, suggesting that $\operatorname{PrP}^{\mathrm{c}}$ was either cleared or masked by the interaction with SAF34.

To study the effect of the antibody treatment on the toxicity induced by the prion peptide 106-126, we have carried out toxicity assays on cells treated for $24 \mathrm{hr}$ with the antibody. The MTS assay (Fig. 5) showed that the measured values remained equivalent in the presence of the SAF antibody suggesting that the toxicity of the peptide is independent of the cellular prion protein.

We have shown previously that the PrP 106-126 induced a destabilization of lipidic liposomal vesicles indicating that the toxicity effect of this peptide could occur via a membrane interaction (Dupiereux et al., 2005b); this in turn suggests that lipidic components could play a key role in the toxicity of $\operatorname{PrP} 106-126$ peptide.

\section{Rabbit Kidney Epithelial Cells Are Resistant to Prion Peptide 106-126 Toxicity}

To further investigate the relationship between the basal expression of $\operatorname{PrP}^{\mathrm{C}}$ and the neurotoxicity induced by the peptide 106-126 we used a cell model (rabbit kidney epithelial cells) that expresses low levels of $\operatorname{PrP}^{\mathrm{c}}$ but in which murine $\operatorname{PrP}^{\mathrm{c}}$ can be selectively induced by doxycycline (Vilette et al., 2001c).

Treatment with doxycycline $(10-1,000 \mathrm{ng} / \mathrm{ml})$ induced the expression of $\mathrm{PrP}^{\mathrm{C}}$, as shown by Western blotting (Fig. 6). Conversely, in the absence of doxycycline no endogenous $\operatorname{PrP}^{\mathrm{c}}$ was detected in these cells (Vilette et al., 2001b).

In these cells, we have shown that the absence or the presence of doxycycline (absence or presence of $\mathrm{PrP}^{\mathrm{C}}$ expression), does not change the PrP 106-126 toxicity (Fig. 7). The incompatibility between the human sequence of $\operatorname{PrP} 106-126$ and the murine $\mathrm{PrP}$ can be discarded; indeed, we have shown by MTS assay, that the same peptide is neurotoxic for murine neuroblastoma cells (N2a) expressing a murine PrP in the same concentration range of $\operatorname{PrP} 106-126$ inducing 50\% cell death at $200 \mu \mathrm{M}$ (data not shown). These data indicate that the PrP expression is not required for PrP106-126 toxicity.

The difference in the susceptibility of these two tested cell lines (neuronal and non neuronal), toward the PrP 106-126 peptide, might be related to the composition of the lipidic cell membrane. To study the putative implication of the lipids, the fatty acid composition of the cellular membrane of SH-SY5Y and A74 was compared (Table I). Significant differences were observed between these two cell lines and in particular in the composition of their unsaturated fatty acids. Indeed, the content in unsaturated fatty acids in the neuroblastoma cells was significantly higher than in the rabbit kidney epithelial cells. The most unsaturated fatty acids in the neuronal cells were palmitoleic acid (16:1), vaccenic acid (18:1), arachidonic acid (20:4), docosapentaenoic acid (22:5), and docosahexaenoic acid (22:6). These data suggest that the susceptibility to the prion peptide 106-126 could be related to the fatty acid composition of the cellular membranes. Our observation reinforces the hypothesis of a direct interaction of the prion 106-126 peptide with the lipidic membrane.

\section{Enhanced Toxicity of PrP 106-126 on the \\ Neuroblastoma Cell Line in the Presence of Palmitic Acid}

Based on fatty acid analysis we observed different saturated and non saturated fatty acid composition between the neuronal and non neuronal cell lines used in this study. Indeed, amongst others, palmitic acid, vaccenic acid and docosahexaenoic acid were present in low amounts in the PrP 106-126 resistant non neuronal 


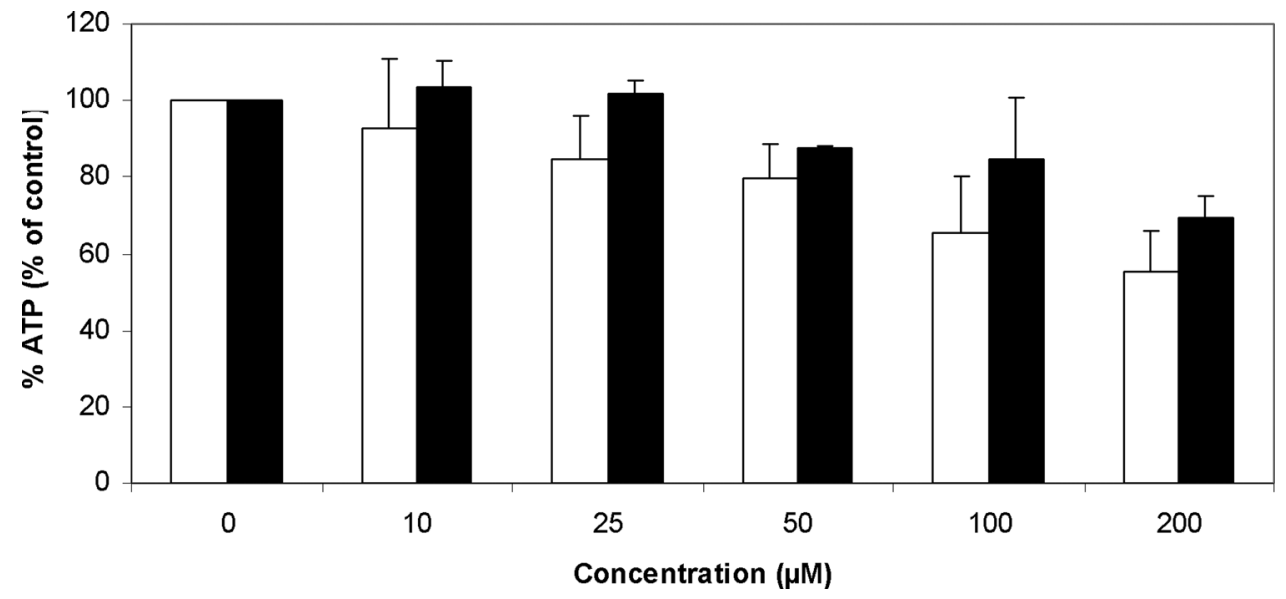

Fig. 3. Effect of $\operatorname{PrP} 106-126$ on intracellular ATP levels of cells. SHSY5Y (white bars) or wtPrP (black bars) were treated for $24 \mathrm{hr}$ with different concentrations of PrP 106-126 (10$200 \mu \mathrm{M})$. Data are expressed as a percentage of control (non-PrP 106-126 treated cells) and represent the mean percentage \pm SD from triplicate experiments repeated three times (nine observations).
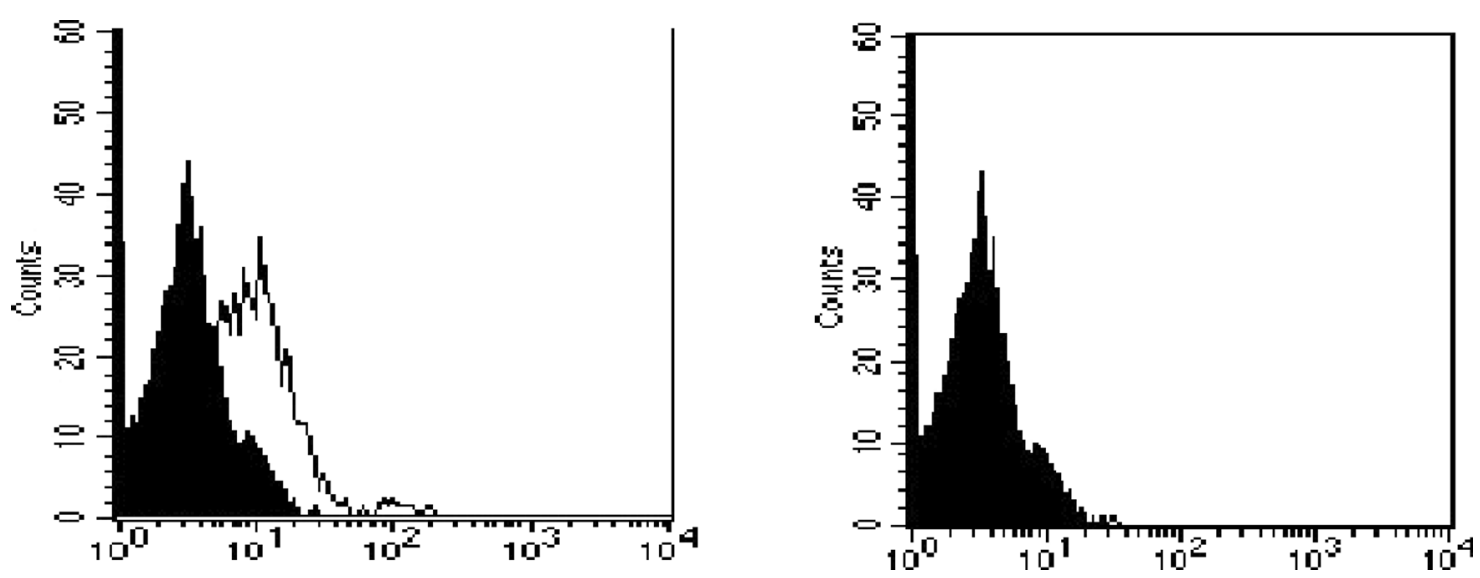

Fig. 4. Flow cytometry detection of $\operatorname{PrPc}$ expression in the absence (A) or in the presence $(\mathbf{B})$ of SAF 34. SH-SY5Y cells were incubated for $24 \mathrm{hr}$ with the anti-prion antibody SAF 34 and $\operatorname{PrP}^{\mathrm{c}}$ was detected with a biotinylated antibody SAF34 $(10 \mu \mathrm{g} / \mathrm{ml})$ for $30 \mathrm{~min}$ at $4{ }^{\circ} \mathrm{C}$ (white histogram).

The control cells were not incubated with the antibody biotinylated SAF34 (black histogram).

cell line. In the present work we were mainly interested on the potential implication of palmitic acid, a representative cell membrane fatty acid, in this resistance.

To evaluate whether palmitic acid triggered $\mathrm{PrP}$ 106-126 cytotoxicity, we determined the synergistic toxic effect of palmitic acid and prion peptide on the neuronal (SH-SY5Y) and non neuronal (A74) cell lines. Cell viability as measured by MTS assay is shown in Figpre-treated cells after a $24 \mathrm{hr}$ exposure to $200 \mu \mathrm{M} \operatorname{PrP}$ 106-126. As expected, PrP 106-126 led to a 50\% survival for the neuronal cell line (SH-SY5Y) whereas no toxicity was observed for the rabbit kidney epithelial cell line (A74). In contrast, SH-SY5Y pre-treated with palmitic acid showed significant susceptibility to the toxic effect of prion peptide with a cell death increase of $10 \%$, whereas palmitic acid alone did not affect cell viability. Surprisingly, the non neuronal A74 cell line pre-treated with palmitic acid remained resistant to the PrP 106126 toxicity.

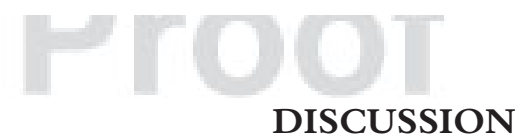

$\operatorname{PrP} 106-126$ peptide is a useful model for the in vitro study of prion-induced cell suffering. Indeed, this peptide exhibits some of the pathogenic and physicochemical properties of $\operatorname{PrP}^{\mathrm{sc}}$. It is able to form proteaseresistant fibrils, induce neuronal toxicity, and has a relatively high $\beta$-sheet content (Tagliavini et al., 2001). However the mechanism by which this peptide induces alterations in neuronal cells is not well understood. Does this occur by direct membrane interactions or via membrane receptors?

We have studied the relationship between the expression of $\operatorname{PrP}^{\mathrm{c}}$, the lipidic membrane composition, and the toxicity induced by the prion peptide 106-126.

It is widely accepted that $\operatorname{PrP}^{\mathrm{c}}$ is necessary for the toxicity of $\operatorname{PrP}^{\text {sc }}$ (Bueler et al., 1993; Brandner et al., 1996). This dependence on $\operatorname{PrP}^{c}$ and toxicity of $\operatorname{PrP}$ 106-126 has also been indicated (Brown et al., 1994; Chabry et al., 2003b; Fioriti et al., 2005d). Nevertheless, 
Fig. 5. Effect of SAF 34 on the toxicity induced by PrP106-126 in SH-SY5Y and wtPrP cells. The viability was measured in untransfected SH-SY5Y cells (white bars) or wtPrP-expressing cells (black bars) both exposed to $\operatorname{PrP} 106-$ 126 at $200 \mu \mathrm{M}$ for $24 \mathrm{hr}$ after a preincubation of $3 \mathrm{hr}$ in the presence or absence of SAF 34. Each value represents the mean percentage $\pm \mathrm{SD}$ from triplicate experiments repeated three times (nine observations).

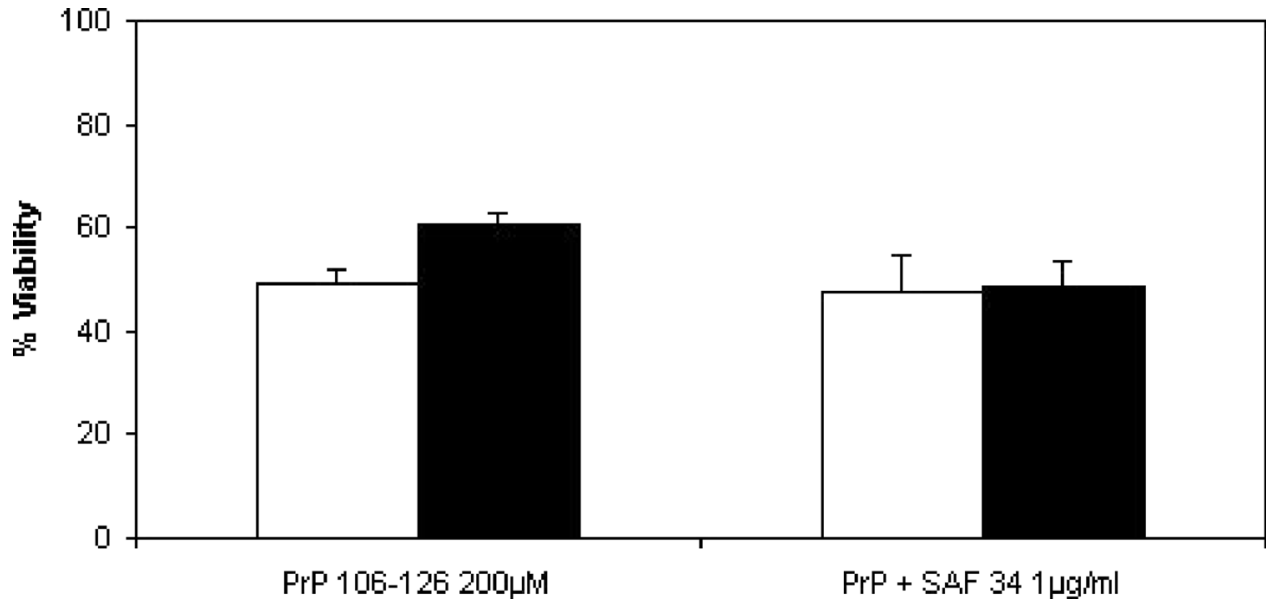

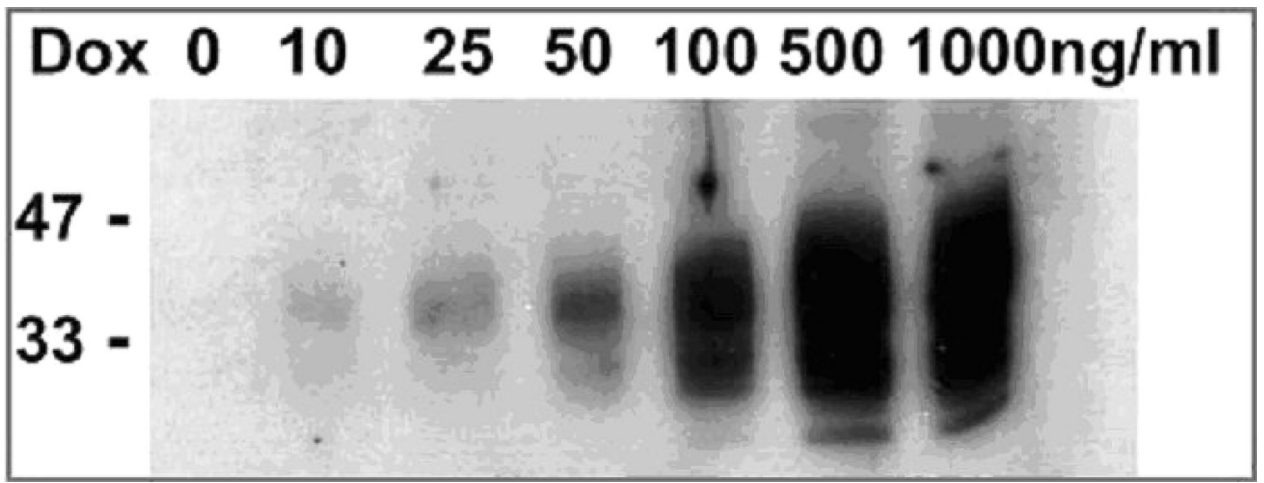

Fig. 6. Doxycycline-dependent induction of $\mathrm{PrP}^{\mathrm{c}}$ expression in $\mathrm{A} 74$ cells. Dox was added at different concentrations $(0,10,25,50,100$, 500 , and $1,000 \mathrm{ng} / \mathrm{ml}$ ) to medium for $24 \mathrm{hr}$, and $\mathrm{PrP}^{\mathrm{c}}$ expression was determined in A74 cells by Western blot. The equivalent of $20 \mu \mathrm{g}$ of protein were subjected to SDS-PAGE and $\operatorname{PrP}^{c}$ was detected with antibody P45-66 raised against the $\mathrm{N}$ terminus of the protein. $\operatorname{PrP}^{c}$ expression reaches a maximum at $500 \mathrm{ng} / \mathrm{ml}$ of dox; after this concentration we reach a plateau. Molecular mass markers are indicated on the left in $\mathrm{kDa}$.
Fig. 7. Effect of $\operatorname{PrP} 106-126$ on a rabbit kidney epithelial cells (A74) in relation with the expression level of $\operatorname{PrP}^{c}$. A74 cells were seeded at 5,000 cells/ well and stimulated with doxycycline (50 and $500 \mathrm{ng} / \mathrm{ml}$ ) $24 \mathrm{hr}$ before $\operatorname{PrP}$ 106-126 exposure at different concentrations: $50 \mu \mathrm{M}$ (white bars); $100 \mu \mathrm{M}$ (black bars). Viability was measured by MTS assay. Each value represents the mean percentage \pm SD from triplicate experiments repeated three times (nine observations).

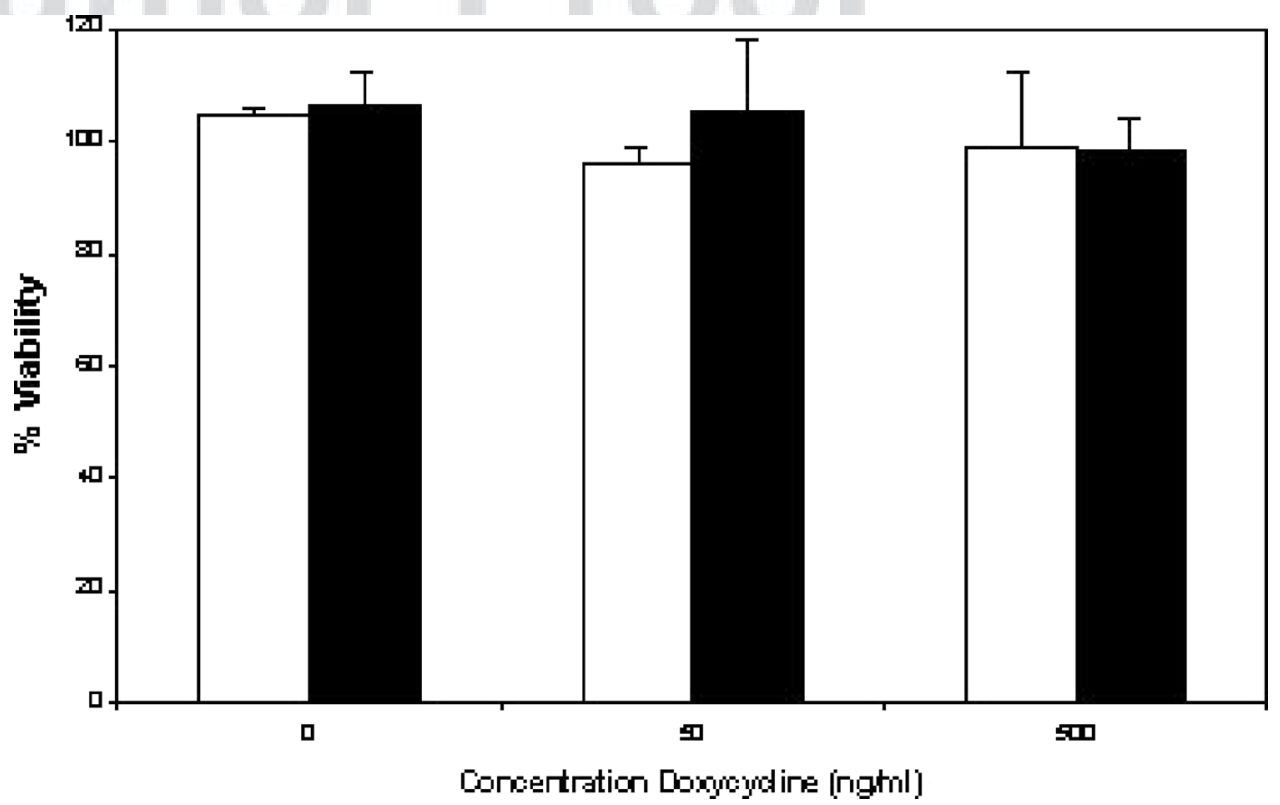


the mechanism of toxicity remains unclear and contradictory data about the relation between $\operatorname{PrP}^{c}$ expression and the toxicity induced by $\operatorname{PrP}^{\mathrm{sc}}$ or $\operatorname{PrP} 106-126$ have been reported. Several works have shown that the prion peptide 106-126 is toxic to cultured neurons and that neurons derived from Prnp ${ }^{-/-}$mice are resistant to this peptide (Brown et al., 1994; Chabry et al., 2003c). Fioriti et al. (2005a) using cerebellar granule neurons derived from wild-type mice and $\mathrm{Tg}$ mice overexpressing mouse $\operatorname{PrP}$, did not detect any difference in the toxicity of $\operatorname{PrP}$ 106-126 on both cell lines. Conversely, they did not observe any toxicity of the peptide on the knock-out cell line. These data suggest that the expression of $\operatorname{PrP}^{c}$ is necessary for the toxicity induced by the peptide but that the level of expression does not modulate this neurotoxicity. The authors propose to explain the toxicity of $\operatorname{PrP} 106-126$ by the physiologic loss of $\operatorname{PrP}^{\mathrm{c}}$. Further-

TABLE I. Comparative Study of Fatty Acid Composition of the Cellular Membrane of SH-SY5Y and A74 Cells

\begin{tabular}{lcc}
\hline Phospholipidics fatty acids & $\begin{array}{c}\text { Neuronal cells } \\
\text { (SH-SY5Y) }\end{array}$ & $\begin{array}{c}\text { Non neuronal } \\
\text { cells (A74) }\end{array}$ \\
\cline { 2 - 3 } Myristic acid & \multicolumn{1}{c}{ Mmol/kg } & $\mu \mathrm{mol} / \mathrm{kg}$ \\
Nentadecyclic acid & 144 & 923 \\
Nalmitic acid & 10,247 & 674 \\
Nalmitoleic acid & 1,276 & 5,765 \\
Stearic acid & 3,596 & 701 \\
T-vaccenic acid & 187 & 2,460 \\
Oleic acid & 8,928 & 68 \\
C-vaccenic acid & 3,165 & 8,814 \\
Linolenic acid & 572 & 195 \\
Gamma linolenic acid & 25 & 520 \\
Alpha linolenic acid & 49 & 22 \\
Gadoleic acid & 209 & 32 \\
Dihomo-g-linolenic acid & 124 & 329 \\
Arachidonic acid & 1,974 & 177 \\
Eicosapentaenoic acid & 96 & 1,390 \\
Docosapentaenoic acid & 999 & 612 \\
Docosahexaenoic acid & 2,420 & 98 \\
\hline
\end{tabular}

more, Gu et al. (2001) have shown that in a human neuronal cell line resistant to the $\operatorname{PrP} 106-126$ toxicity, the prion peptide binds at the cell surface and that some of the resistant neuronal cells internalize the peptide that accumulate in intracellular compartments. They concluded that the resistance to the toxicity induced by $\operatorname{PrP}$ 106-126 seemed to be related to an aberrant binding of the peptide with the membranes. Currently, it is known that such an aberrant binding with the cellular membrane can be induced by an alteration in the membrane lipidic composition.

In the present study, we have analyzed the toxicity of the peptide on a neuroblastoma cell line expressing different levels of $\operatorname{PrP}^{\mathrm{c}}$. Our results show that the toxicity of $\operatorname{PrP} 106-126$ is independent of the expression level of the cellular prion protein, as shown by Fioriti and collaborators (Fioriti et al., 2005c). To study the implication of the endogenous levels of cellular prion protein in the toxicity induced by the peptide, we have used an original strategy based on the ability of an antiprion antibody (SAF34) to inhibit $\operatorname{PrP}^{\mathrm{sc}}$ replication and to decrease the levels of total $\operatorname{PrP}^{c}$ and $\operatorname{PrP}^{\mathrm{sc}}$ in an infected cell model (Feraudet et al., 2005b). We have shown by MTS assay that an incubation of SH-SY5Y with SAF34 did not reduce the toxic effect of the peptide 106-126 indicating that endogenous levels of the cellular prion protein is not directly implicated in the toxicity of the peptide. Because we cannot exclude the possibility that residual $\mathrm{PrP}^{\mathrm{c}}$ is left in our cells after the antibody treatment, we propose that a sub-physiological level or an appropriated lipid composition could be required for peptide toxicity.

Our finding is consistent with other reports indicating that the toxicity of $\operatorname{PrP}^{s c}$ and $\operatorname{PrP} 106-126$ is independent of the expression of $\operatorname{PrP}^{c}$. Indeed, it has been shown that $\operatorname{PrP}^{\mathrm{sc}}$ and $\operatorname{PrP} 106-126$ may cause an upregulation of the MAP kinases signalling pathway inducing neurotoxicity in Prnp ${ }^{-1-}$ cells (Gavin et al., 2005; Marella et al., 2005). Furthermore, McHattie et al. (1999) have studied the cellular trafficking of the prion peptide 106-126 and have observed that cultured cells are capa-

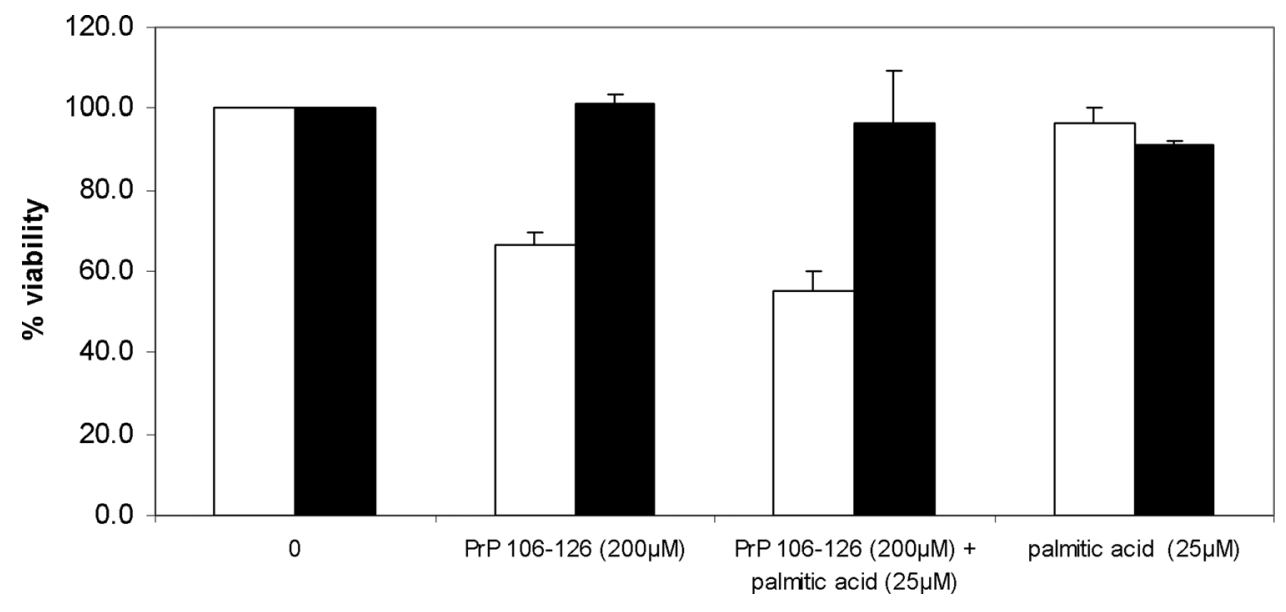

Fig. 8. Effect of palmitic acid on the toxicity induced by $\mathrm{PrP} 106-126$ in SH-SY5Y and A74 cells. The viability was measured in SH-SY5Y cells (white bars) and A74 cells (black bars) both exposed to $\operatorname{PrP} 106-126$ at $200 \mu \mathrm{M}$ for $24 \mathrm{hr}$ after a pre-incubation of $16 \mathrm{hr}$ in the presence or absence of palmitic acid (25 $\mu \mathrm{M})$. Each value represents the mean percentage $\pm \mathrm{SD}$ from triplicate experiments repeated three times (nine observations). 
ble of sequestering the peptide independent of $\operatorname{PrP}^{c}$ expression.

These results suggest that the toxic mechanism of this peptide is independent of a direct interaction with $\operatorname{PrP}^{\mathrm{c}}$ and indicate that a direct insertion of $\operatorname{PrP} 106-126$ into the cell membrane, particularly in cholesterol-rich lipid domains, named rafts, could induce disturbances. We have shown recently that the 106-126 peptide destabilizes lipid vesicles mimicking the composition of neuronal membranes and that it induces liposome fusion. This destabilization occurred via a membrane interaction as was shown by the integrity membrane assay (Dupiereux et al., 2005c).

Using a non-neuronal cell line in which the expression of $\mathrm{PrP}^{\mathrm{c}}$ could be selectively induced by doxycycline (Vilette et al., 2001a), no toxicity was observed in the presence and in the absence of $\operatorname{PrP}^{\mathrm{c}}$. These data are in agreement with the results obtained on the neuroblastoma cells and suggest that the toxicity induced by PrP 106-126 could be dependent on the composition of the cellular membrane as was shown by the fatty acids analysis. We have observed that the effect of toxicity induced by the $\operatorname{PrP} 106-126$ prion peptide was more pronounced in the presence of palmitic acid whereas, no effect was observed for the non-neuronal cell line A74. The mechanism as to how palmitic acid could increase the prion peptide toxicity was not investigated in the present study and needs to be further explored; these results must be thoroughly studied by testing different other lipid factors but at the current state of the work, we can suggest that the palmitic acid enhances binding or internalization of the peptide into the lipid membrane. It has been reported that fatty acids with longer acyl chains (C12-18) cause a reduction in the fluidity of the cellular membranes affecting cell membrane function (Johnson et al., 2003) and inducing apoptosis. Our results seem to indicate that the cellular membrane fatty acid composition could be an important modulator factor in the neurodegeneration observed in prion pathology. This is probably by altering the physicochemical properties of cell membranes favoring the membrane interaction of pathologic prion protein with the cell membranes.

In conclusion, we reinforce the hypothesis that the toxicity induced by the prion peptide 106-126 may not be due only to direct interaction with $\operatorname{PrP}^{c}$ and that the key event in this toxicity could be a direct interaction with the lipidic components of cell membranes. A destabilization of membrane lipids could interfere with $\operatorname{PrP}^{\mathrm{c}}$ function and may facilitate access of the peptide to intracellular targets.

Our current results reinforce previous observations (Chen et al., 1995; Jeffrey et al., 2004b) proposing that, during prion diseases, the novo-transconformed $\operatorname{PrP}^{\mathrm{sc}}$ could be cleaved in toxic prion protein fragments responsible of neuronal dysfunction and death. Even more, these peptides may diffuse and intoxicate adjacent PrPnegative cells; this hypothesis might explain neuronal death in transgenic mice knock-out for the Prnp gene except in astrocytes after $\operatorname{PrP}^{\mathrm{sc}}$ infection (Jeffrey et al., 2004a).

\section{ACKNOWLEDGMENTS}

We thank Professor G. Deby and Dr. A. MouithysMickalad for fruitful discussions, Professor D. Harris for providing the rabbit polyclonal antibody P45-66, and Professor N.M. Hooper for providing the neuroblastoma cell line.

\section{REFERENCES}

Arispe N, Pollard HB, Rojas E. 1996. Zn2+ interaction with Alzheimer amyloid beta protein calcium channels. Proc Natl Acad Sci USA 93: 1710-1715.

Baron GS, Wehrly K, Dorward DW, Chesebro B, Caughey B. 2002. Conversion of raft associated prion protein to the protease-resistant state requires insertion of $\mathrm{PrP}$-res $(\mathrm{PrP}(\mathrm{Sc}))$ into contiguous membranes. EMBO J 21:1031-1040.

Brandner S, Isenmann S, Raeber A, Fischer M, Sailer A, Kobayashi Y, Marino S, Weissmann C, Aguzzi A. 1996. Normal host prion protein necessary for scrapie-induced neurotoxicity. Nature 379:339-343.

Brown DR, Herms J, Kretzschmar HA. 1994. Mouse cortical cells lacking cellular $\operatorname{PrP}$ survive in culture with a neurotoxic PrP fragment. Neuroreport 5:2057-2060.

Bueler H, Aguzzi A, Sailer A, Greiner RA, Autenried P, Aguet M, Weissmann C. 1993. Mice devoid of PrP are resistant to scrapie. Cell 73: 1339-1347.

Caughey B, Lansbury PT. 2003. Protofibrils, pores, fibrils, and neurodegeneration: separating the responsible protein aggregates from the innocent bystanders. Annu Rev Neurosci 26:267-298.

Caughey B, Raymond GJ. 1991. The scrapie-associated form of PrP is made from a cell surface precursor that is both protease- and phospholipase-sensitive. J Biol Chem 266:18217-18223.

Chabry J, Ratsimanohatra C, Sponne I, Elena PP, Vincent JP, Pillot T. 2003. In vivo and in vitro neurotoxicity of the human prion protein (PrP) fragment P118-135 independently of PrP expression. J Neurosci 23:462-469.

Chen SG, Teplow DB, Parchi P, Teller JK, Gambetti P, Autilio-Gambetti L. 1995. Truncated forms of the human prion protein in normal brain and in prion diseases. J Biol Chem 270:19173-19180.

Clinton J, Forsyth C, Royston MC, Roberts GW. 1993. Synaptic degeneration is the primary neuropathological feature in prion disease: a preliminary study. Neuroreport 4:65-68.

Collins SJ, Lawson VA, Masters CL. 2004. Transmissible spongiform encephalopathies. Lancet 363:51-61.

Diomede L, Sozzani S, Luini W, Algeri M, De GL, Chiesa R, Lievens PM, Bugiani O, Forloni G, Tagliavini F, Salmona M. 1996. Activation effects of a prion protein fragment [PrP-(106-126)] on human leucocytes. Biochem J 320:563-570.

Dupiereux I, Zorzi W, Lins L, Brasseur R, Colson P, Heinen E, Elmoualij B. 2005. Interaction of the 106-126 prion peptide with lipid membranes and potential implication for neurotoxicity. Biochem Biophys Res Commun 331:894-901.

Feraudet C, Morel N, Simon S, Volland H, Frobert Y, Creminon C, Vilette D, Lehmann S, Grassi J. 2005. Screening of 145 anti-PrP monoclonal antibodies for their capacity to inhibit PrPSc replication in infected cells. J Biol Chem 280:11247-11258.

Fioriti L, Quaglio E, Massignan T, Colombo L, Stewart RS, Salmona M, Harris DA, Forloni G, Chiesa R. 2005. The neurotoxicity of prion protein $(\mathrm{PrP})$ peptide 106-126 is independent of the expression level of $\mathrm{PrP}$ and is not mediated by abnormal PrP species. Mol Cell Neurosci 28:165-176.

Fraser H. 1993. Diversity in the neuropathology of scrapie-like diseases in animals. Br Med Bull 49:792-809. 
Gajdusek DC, Gibbs CJ, Alpers M. 1966. Experimental transmission of a Kuru-like syndrome to chimpanzees. Nature 209:794-796.

Gavin R, Braun N, Nicolas O, Parra B, Urena JM, Mingorance A, Soriano E, Torres JM, Aguzzi A, del Rio JA. 2005. PrP(106-126) activates neuronal intracellular kinases and Egr1 synthesis through activation of NADPH-oxidase independently of PrPc. FEBS Lett 579:4099-4106.

Gu Y, Jing Y, Kumar A, Sharma Y, Fujioka H, Singh N. 2001. Isolation of human neuronal cells resistant to toxicity by the prion protein peptide 106-126. J Alzheimers Dis 3:169-180.

Jeffrey M, Goodsir CM, Race RE, Chesebro B. 2004. Scrapie-specific neuronal lesions are independent of neuronal $\mathrm{PrP}$ expression. Ann Neurol 55:781-792.

Jeffrey M, Halliday WG, Bell J, Johnston AR, MacLeod NK, Ingham C, Sayers AR, Brown DA, Fraser JR. 2000. Synapse loss associated with abnormal PrP precedes neuronal degeneration in the scrapie-infected murine hippocampus. Neuropathol Appl Neurobiol 26:41-54.

Johnson RA, Hamilton JA, Worgall TS, Deckelbaum RJ. 2003. Free fatty acids modulate intermembrane trafficking of cholesterol by increasing lipid mobilities: novel 13C NMR analyses of free cholesterol partitioning. Biochemistry 42:1637-1645.

Kawahara M, Kuroda Y, Arispe N, Rojas E. 2000. Alzheimer's betaamyloid, human islet amylin, and prion protein fragment evoke intracellular free calcium elevations by a common mechanism in a hypothalamic GnRH neuronal cell line. J Biol Chem 275:14077-14083.

Marella M, Gaggioli C, Batoz M, Deckert M, Tartare-Deckert S, Chabry J. 2005. Pathological prion protein exposure switches on neuronal mitogen-activated protein kinase pathway resulting in microglia recruitment. J Biol Chem 280:1529-1534.

McHattie SJ, Brown DR, Bird MM. 1999. Cellular uptake of the prion protein fragment PrP106-126 in vitro. J Neurocytol 28:149-159.

Perrier V, Solassol J, Crozet C, Frobert Y, Mourton-Gilles C, Grassi J, Lehmann S. 2004. Anti-PrP antibodies block PrPSc replication in prion-infected cell cultures by accelerating PrPC degradation. J Neurochem 89:454-463.

Prusiner SB. 1998. Prions. Proc Natl Acad Sci USA 95:13363-13383.

Salmona M, Forloni G, Diomede L, Algeri M, De GL, Angeretti N, Giaccone G, Tagliavini F, Bugiani O. 1997. A neurotoxic and gliotropic fragment of the prion protein increases plasma membrane microviscosity. Neurobiol Dis 4:47-57.

Tagliavini F, Forloni G, D'Ursi P, Bugiani O, Salmona M. 2001. Studies on peptide fragments of prion proteins. Adv Protein Chem 57:171-201.

Taraboulos A, Scott M, Semenov A, Avrahami D, Laszlo L, Prusiner SB. 1995. Cholesterol depletion and modification of $\mathrm{COOH}$-terminal targeting sequence of the prion protein inhibit formation of the scrapie isoform. J Cell Biol 129:121-132.

Vilette D, Andreoletti O, Archer F, Madelaine MF, Vilotte JL, Lehmann S, Laude H. 2001. Ex vivo propagation of infectious sheep scrapie agent in heterologous epithelial cells expressing ovine prion protein. Proc Natl Acad Sci USA 98:4055-4059.

Walmsley AR, Zeng F, Hooper NM. 2001. Membrane topology influences $\mathrm{N}$-glycosylation of the prion protein. EMBO J 20:703-712. 